Meta

Journal des traducteurs

Translators' Journal

\title{
Methodology in Translation Criticism
}

\section{Ekundayo O. Simpson}

Volume 20, numéro 4, décembre 1975

URI : https://id.erudit.org/iderudit/004157ar

DOI : https://doi.org/10.7202/004157ar

Aller au sommaire du numéro

Éditeur(s)

Les Presses de l'Université de Montréal

ISSN

0026-0452 (imprimé)

1492-1421 (numérique)

Découvrir la revue

Citer cet article

Simpson, E. O. (1975). Methodology in Translation Criticism. Meta, 20(4),

251-262. https://doi.org/10.7202/004157ar d'utilisation que vous pouvez consulter en ligne.

https://apropos.erudit.org/fr/usagers/politique-dutilisation/ 


\section{Methodology in Translation Criticism}

From time immemorial, a lot of interest has been shown in the translator and the result of his efforts. The same cannot be said, however, of the translator's critic. One glaring effect of this situation has been the absence of what we may call critical standards in assessing translations. We shall in this essay attempt to highlight some of the major problems involved in translation criticism, with a view to arriving at possible criteria for the evaluation of translations. It is, perhaps, necessary to start by examining some of the fundamental issues which have in the past tended, and still continue, to determine the course of translation criticism.

Whereas we would hardly give any thought today to the question of why we have to translate, the question still appeared to be of some interest to scholars not long ago. Nor is it particularly important these days to know who should translate, and who should not. What appears to matter now is the end-product of translating effort. The suggestion by André Gide that writers, and writers only, should translate, can then be seen as typical of past ideas on translation. We shall come back to this point later. Suffice it to say here that although Gide must have had only works of creative writing in mind, many a writer has been known to commit «howlers » and general errors of translation while working on creative writing.

One other area of contention in the past centred around whether it was always possible to transmit completely from one language into another, the different facets, shades of meaning, of a given message. Once again, literary texts, and the problems they pose for translation, have often been the testing-ground for this particular aspect of translation.

Because of the special problem involved in the translation of poetry, for instance, it has often been stated that a poem, like many other forms of creative writing cannot, and therefore should not, be translated. Indeed, the greatest source of difficulty in translating a work of art, especially poetry, is how not to sacrifice, form for content, or vice versa, since form quite often determines content, and content form. The feeling that " a poem should not mean but be ${ }^{1}$ 》 makes the task of the translator an arduous one. Can the translator always reproduce the effect of the original work in a new idiom? And where he can - but hardly can any work

1. Archibald Macleish, quoted by D. Fitts, "The Poetic Nuance », in Reuben A. Brower (édit.), On translation, Cambridge (Mass.), Harvard University Press, 1959, p. 79. 
have exactly the same impact on different individuals - can he, as in the case of poetry, reproduce accurately the rhythm and rime, assonance, word-play and all the other accoutrements of writing that go to make up the style and the essence of the original? Many a translator has often felt the need to sacrifice one aspect of the total make-up of a piece of writing for another ${ }^{2}$.

However, although attention is still often focussed on the problems raised by the form/content or effect/meaning relationship in translation, the old dogma of untranslatability no longer holds. It is now obvious that since human experience and conception of the world are not everywhere the same, certain experiences would resist exact transmission into certain other languages. Differences in ex perience or understanding of the world, or even the total absence of certain experiences in certain parts of the world, are thus normally reflected in the languages representing such areas. Humboldt had already pointed out this fact over a hundred years ago. But that most human experiences can be mutually represented from language to language cannot be denied. Borrowing is one of the most direct ways of taking care of linguistic deficiency. Roman Jakobson put it this way :

All cognitive experience and its classification is conveyable in any existing language. Whenever there is deficiency, terminology may be qualified and amplified by loanwords or loan-translations, neologisms or semantic shifts, and finally by circumlocutions ${ }^{3}$.

This is not to say, however, that one cannot talk of «gains》 and «losses 》 in translation.

If we now go back to André Gide, we find that behind his call for translation to be done by writers, and writers only, is another point of past controversy : the idea that translation belongs to the realm of art. This question too has been carried down to our times. The Russian, Fedorov, was one of the first scholars to claim for translation a place in the world of linguistics at a time when most people still talked of the « art of translation». The result was an onslaught of criticism, reflecting contrary views, by his compatriots. Similarly, when Vinay and Darbelnet, the authors of Stylistique comparée du français et de l'anglais : méthode de traduction, contended that the translator's task required first and foremost linguistic skill, Edmond Cary lost no time in criticizing their view. For Cary, literary translation is a literary operation ${ }^{4}$.

2. Vladimir Nabokov, in his essay "The Servile Path ", in Brower, op. cit., p. 97, pinpoints the poetry translator's plight, and excuses himself when he asserts (after translating Eugene Onegin, Pushkin's Russian novel in verse, into English) : " In my translation I have sacrified to total accuracy and completeness of meaning every element of form save the iambic rhythm, the retention of which assisted rather than impaired fidelity, "s

3. Roman Jakobsen, "On linguistic Aspects of Translation ", in Brower, op. cit., p. 234.

4. Edmond Cary, quoted by Georges Mounin, les Problèmes théoriques de la traduction, Paris, Gallimard, 1963, p. 43, states categorically : "La traduction littéraire n'est pas une opération linguistique, c'est une opération littéraire." Vinay and Darbelnet had stated, however, on p. 20-21 of Stylistique comparée du français et de l'anglais: méthode de traduction, revised edition, Montréal, Beauchemin, 1970, that translation goes hand in hand with comparative stylistics, "reposant sur des constantes déjà, dégagées par les linguistes pour chaque langue séparément et qui maintenant s'affrontent au cours du processus de la traduction. Cette dernière ne serait donc pas uniquement un art, résultat d'une inspiration qui permettrait seule de reconnaître la présence d'un équivalent véritable. " 
Apart from the very obvious fact that translation is a typical example of language contact both in the sense that two languages actually converge in the mind of the translator during the process of translation, and also that the source language quite often rubs off on the target language, the very nature of semantics, the science of meaning and the cornerstone of all translation, situates translation squarely in the domain of linguistics : "Le traducteur part du sens et effectue toutes ses opérations de transfert à l'intérieur du domaine sémantique ${ }^{5}$.

The true place of translation was further clarified by Saussure's definition of the linguistic sign, for it threw greater light on what should constitute the smallest unit of translation. The tendency, before Saussure's definition had been to regard the word as being generally equivalent to the linguistic sign. But the author of Cours de linguistique générale showed that the word is indeed part of the sign, indissociable from it; sign $=$ concept + acoustic medium, i.e. the word. This means that the smallest unit of translation cannot always be the word, but rather the smallest unit of thought, as pointed out by Vinay and Darbelnet.

That translation belongs to linguistics reposes, however, on criteria much more far-reaching than semantics or the possibility of language contact (aspect of bilingualism). Inasmuch as the juxtaposition of two bodies of statements in two languages, known to be equivalent to each other in message, can inform us of the different resources of the two languages, their structure, the culture and mental attitude behind each of them (and these are often diametrically opposed), then the study of translation and all the different processes involved in it can prove a fertile ground for linguistics, especially « external » stylistics.

The field of comparative stylistics (when we shall define as the comparison of the genius of one language with that of another) then stands out clearly as a field which requires, rather than just artistic intuition, precise linguistic knowledge and discipline. The symbiotic relationship between translation and comparative stylistics is quite obvious.

\section{TYPOLOGY OF TRANSLATION CRITICISM}

Now that most of the earlier prejudices and misconceptions about translation have disappeared, or are disappearing in favour of more realistic views, translation criticism should reflect the new awareness. But perhaps because of the impact of the views referred to above, the bulk of relevant criticism still appears to be done from a narrow, « partial » angle.

Since literary translations constitute a major part of translated material, it is not surprising that critics have taken so much interest in the literary aspects of translation, and little else. Thus many scholars have undertaken the study of translated texts only so as to show, for instance, how such translations can be a commentary, as it were, on the tastes and views, likes and dislikes of the period which produced them. Douglas Knight's essay on translation during the Augustan period highlights this kind of approach :

5. Vinay and Darbelnet, op. cit., p. 37. 
The Augustans, it should be clear, are forced to an awareness of themselves which few ages have accepted so candidly. They have a far more specific and accurate knowledge, for example, of the great work in the Greco-Roman tradition-than even the best-minded Elizabethans possess. But the very fact of that knowledge stands for them as a commentary on themselves. Chapman interprets and translates Homer in exaltation of his own World ${ }^{6}$.

Every age has always felt the need to adapt old translations into the latest idiom so as to make such translations more easily understood by the contemporary generation. The different versions of the English translation of the Bible are a case in point. But Chapman does more than that, according to Knight. He puts into his translation what the people of his own age would like to see in a great work. And that is Knight's main interest in such a translation. Another critic, Brower, was able to «illustrate the usefulness of translations for the historian of literature and the historian of ideas » in his study, «Seven Agamemnons »:

When a writer sets out to translate - say, the Agamemnon - what happens? Much, naturally, that we can never hope to analyze. But what we can see quite clearly is that he makes the poetry of the past into poetry of his particular present ${ }^{7}$.

We can assume that a good deal of what Brower says that «we can never hope to analyze » represents those intricacies of translation which the literary critic is less competent to handle. I daresay that those who can analyze such points as Brower is referring to above have not been as active as the literary critics ${ }^{8}$. While one cannot deny the usefulness of criticism done from a literary standpoint (and it is to be encouraged), there is the inherent danger, in this seeming monopoly, that much that could be of great interest to translation in general, and from the linguistic point of view in particular, is left unmentioned and may even escape notice.

Another typical approach is the empirical one, and here it is the translators themselves who are the critics, their own critics. A translator completes his work, he then procedes to tell of his tribulations and discoveries while treading what Nabokov calls « the servile path ». It is normal that this type of critism, a testimony, should often turn out to be subjective, at best too narrow when it is objective. The good point about such criticism, however, is that it often ends with some general guidelines for future translators and from these have emerged different sets of theories based on practice. This has been so right from the earliest days of translation, from St. Jerome to Chateaubriand, Baudelaire, Gide and Valery Larbaud.

Perhaps the most common type of approach to criticism, and this cuts accross typological boundaries, is to skim through the pages of a translation in search of what may not have been properly translated. When such criticism involves the translation of short texts, bilingual notices, road-signs, etc., there is nothing wrong. But this negative approach often involves extensive translation such as long documents and books. And it is quite unfair that so much has been said for

6. Douglas Knight, "Translation : The Augustan Mode », in A. Brower, op. cit., p. 197.

7. Reuben A. Brower, « Seven Agamemnons » in Brower, op. cit., p. 7.

8. The title of an essay published in Meta 17, $\mathrm{n}^{\circ} 2$ (1972), speaks for itself : "Revicwing a Translation : A Practical Problem in Literary Criticism », by Felix Douma. 
instance, about Scott Moncrieff's errors in his translation of Proust's monumental $A$ la recherche $d u$ temps perdu, to the detriment of all the unquestionably good translations found in Remembrance of Things Past. It is of course, a case of the evil than men do living after them, while «the good is off interred with their bones», as Shakespeare put it. This was what Gide was condemning when he said :

In general, I deplore that spitefulness that tries to discredit a translation (perhaps excellent in other regards) because here and there slight mistranslations have slipped in... It is always easy to alert the public against very obvious errors, often mere trifles. The fundamental virtues are the hardest to appreciate and to point out ${ }^{9}$.

However, it would be wrong to conclude that translations have never been explored for their «gems». And by this, we do not mean from the lexico-semantic angle only. Indeed, for over a decade now, comparative stylisticians, translators and linguists have been arriving at valid and useful conclusions about pairs of languages while using translations as their starting point. The pages of Babel and Meta, for instance, continue to reflect the results of such research. And we have already mentioned the book of Vinay and Darbelnet, to which one should add Malblanc's work on French and German ${ }^{10}$. That these works have all succeeded in opening new perspectives for translation cannot be over-emphasized.

But in view of the fact that even at present, translation criticism still seems improvised and is, more often than not, too limited in scope, the need arises for a more objective, comprehensive and systematic approach. Such an approach should aim at facilitating the discovery to a near maximum of the gems contained in a given translated text, especially the longer ones. For there is no denying that if translation is to continue to lay claim, justifiably to being a discipline more than, an art, and if the study and practice of this discipline is to be enhanced, then effort has to be made for its criticism to embrace all that a translated text has to offer.

\section{THE OBJECTIVE AND SYSTEMATIC APPROACH}

In proposing a type of working «formula » for translation criticism, the literarily biased approach will be ruled out, in view of shortcomings and limitations already pointed out above. As for the empirical approach normal with translators, it will be reserved for translators since their experience will always help to give further insight into the problems of translation. These two types of criticism having been seen, to neglect too many of the problems central to translation, the linguistically oriented approach will be recommended, for it alone can situate translation within its right domain. And we have already established this domain beyond any doubt. The linguistic approach also has the advantage of being able to take care of many of the literary points of interest that may arise from the translation of a given text. In short, this approach offers greater chances of leading

9. André Gide, quoted by Justin O'Brien, "From French to English ", in A. Brower, op. cit., p. 90 .

10. Alfred Malblanc, Stylistique comparée du français et de l'allemand: essai de représentation linguistique comparée et étude de traduction, Paris, Didier, 1968, $353 \mathrm{p}$. 
to a comprehensive and mainly objective appraisal of a translation, provided of course that a systematic procedure is adopted.

Having established the ideal basis on which criticism should operate, we may now ask ourselves what the critic is to look out for in the translation before him. Some of the points to look for must, of course, have become obvious at this stage in the essay. If translation is defined as the passage from one language, $A$, to another, $\mathrm{B}$, so as to render the message contained in $\mathrm{A}$, then it is clear that the first duty of the translation analyst is to see whether the message of $A$ has been well and fully rendered into B. It is to be noted, however, that whereas Dr. Johnson's definition of translation is «to change into another language retaining the sense », in our sense of the message there will be more than sense involved. For message contains not only sense, or meaning, but it also reflects the context, situation and tone in which a given idea is expressed. The two statements Donnez votre argent and Aboule ton fric do not represent the same message and it will be wrong to to translate them in the same way. While the first statement hardly gives out its context, the second is charged with information as to possible context and situation. And this points up the fact that the rendering of the message is not limited to the translation of meaning in every case. It also involves problems of idiomatic usage, cultural elements, etc. :

Essentiellement, une traduction doit, pour être à l'abri de tout reproche: 1) transmettre le message de l'original; 2) observer les normes grammaticales de son temps ; 3) être idiomatique ; 4) être dans le même ton que l'original (équivalence stylistique); 5) être pleinement intelligible pour le lecteur qui appartient à une autre culture (adaptation culturelle). ${ }^{11}$

The global message of the text analysed is then seen as being able to be constituted by a combination of all the above factors. It is true that most competent translators so arrive at the right translation that such elements as belong to the domain of grammar and idiom are taken for granted, while the various processes of translation appear natural. The first part of the translation critic's work then is a sort of twocolumn «good» and «bad» inventory reflecting the exactitude, or otherwise, with which the message has been rendered. He must not stop at that.

The next step in the analysis will concern itself with the «bad $\gg$ aspect of the translation, for it is not enough just to point out that such aspect or another of the message has not been properly taken care of. The reason (s) for the mistake, or mistranslation, should be of interest to translation, in particular, and linguistics generally. Is the mistranslation due to faux amis, false association of cognate or non-cognate words, is it due to wrong tonality, unidiomatic use of language, etc ? A corollary of « fault explanation » would then be an attempt at a correct rendering of what has been badly translated.

As from this point on, the attention of the critic should be taken up by some aspects of the translation already established as having been well done. The first point of interest here will be to say why the translation is a good one. Since the greater part of the text is likely to have been well done, the translator will have a

11. Jean Darbelnet, «Traduction littérale ou traduction libre? *, in Meta, 15, $\mathrm{n}^{\circ} \mathrm{2}$ (1970), p. 89 . 
lot to choose from and one is definitely not saying that all that has been well translated should be mentioned. This is impossible. A sort of short-listing is therefore necessary. Such a list will contain some of the most striking examples of the translator's skill, with a discussion of the skill involved. Is the translation of a particular aspect of the text ingenious because of the personal solution arrived at by the translator? Where difficulties that would appear to require a lot of competence have been solved, there will be a discussion of the nature of the problem solved. Furthermore, has the translator created equivalents for which he will long be remembered, like Baudelaire's fidélité de gaze?

The analysis will then take up the translator's ordinary technique and style (his art ?). How "free » is his style, and how literal? Where literal translation is possible, does he often run away from it? Any possible reasons for this may be adduced. Does the translator, for instance, flee from the literal, even though it is possible, because he wants to make his translation more lively and dynamic ? From such an approach, based on the translator's particular use of known techniques and devices of translation, the critic may arrive at general conclusions of interest to translation. The counting-up of particular translation processes may be used here, to make the assessment of the relative use frequency, of such techniques as modulation and transposition more objective. We should point out the obvious here: the examples used to demonstrate the different techniques used by the author here do not have to be the striking cases referred to for the preceding section. They may be the easiest statements to translate or those that hardly require any special skill.

Finally, the last but not the least important point the critic should look for will be those elements in the translation that may be of interest to the comparative stylistics of the two languages in question. We have already called attention to the symbiotic relationship between translation and comparative stylistics. This part of the analysis will consequently bring up such points as relative loopholes in either of the two languages from the point of view of lexis, syntax, structure, morphology, etc, and the striking predominant features of both languages as demonstrated in the translated text. The degree of emphasis here will depend on the originality of the discovery made or the level of frequency with which the particular linguistic phenomenon occurs. The conclusion to the type of systematic approach being suggested will finally make a few general statements and possibly recommendations based on the work just analysed. The critic could, for instance, suggest that a work, a text, be partially or completely retranslated by another translator if he objectively feels that the amount of « betrayal » in the translation is too much.

In order that the type of approach to criticism recommended may be fully appreciated and does not remain a theoretical, intellectual or futile exercise, we shall now proceed to make a model analysis of a translated work of creative writing : Samuel Beckett's translation of his own En attendant Godot. The choice of this work derives from the knowledge that it contains many examples of what the translation critic should look out for in the rendering of the message. The analysis of Beckett's play here will be briefer than normal for lack space. But this essay will have achieved its aim, we hope, if this analysis of one of the great plays 
of the twentieth century clearly illustrates all we have been saying about the objective and systematic approach in translation criticism, with of course a linguistic bias.

\section{BECKETT'S TRANSLATION OF «EN ATTENDANT GODOT 》}

Beckett's En attendant Godot has probably inspired more critical writing than all of his other writings put together. But, like his other translations of his own works, its translation into English by Beckett has hardly ever been studied. The only notable study is Ruby Cohn's essay in which the play was one of Beckett's self-translations examined so as to show how they reflected Beckett's comic intention : «By comparing original with translation, we may gain further insight into Beckett's literary intention and comic method ${ }^{12}$. $\gg$ It is clear that Cohn's study belongs to the class of translation critism referred to above as done from a literary stand-point and that Beckett's deviations from the norm in rendering the global message constitute the main axis of that study of some of his selftranslations.

Beckett's deviations in the translation of En attendant Godot fall under two categories. In the first category, one can see, through the several deletions, additions and outright changes, that the author does not in fact at those points intend to reproduce the message of the source language. It is hard to judge the skill of the author-translator from such translations. On the other hand, one notices that where the author has tried to reproduce the original message, he does from time to time fail to retain the tone of the message. It is with such cases that we can talk of mistranslation.

Of the many changes Beckett brings into the stage directions of Waiting for Godot ${ }^{13}$, the most glaring is the fact that the tree which at the beginning of the second act in French is covered with leaves (L'arbre est couvert de feuilles), has only a few leaves in the English text. But this is really nothing when compared with the discrepancies between the actual dialogues of the two texts. For instance, whereas Estragon's answer in the source language (SL) to Pozzo, who wants to know Vladimir's age, is a curt Demandez-lui, in the target language (TL) his reply is to the effect that Vladimir is eleven years old. Similarly, nothing apparently explains why Estragon should say his name is Catulle at a point in SL but Adam in TL. Equally absurd is the rendering of Lucky's dance, called le cancer des vieillards, as the Hard Stool. But Beckett is not out to give an exact rendering of the message in these cases. Real proof that this is so is also offered by the fact that he actually cuts out at least one page on four different occasions while translating En attendant God'ot: from p. 68 to p. 70 (from VLADIMIR : Il a trouvé to POZZO : Je suis fatigué); from p. 139 (ESTRAGON : Il s'était donc levé ?) to p. 140 (VLADIMIR : C'est toi qui l'as voulu); from p. 148 (VLADIMIR : Ah, tu te rappelles enfin qu'il t'a fait quelque chose) to p. 149 (POZZO: Ils ne le

12. Ruby Cohn, Samuel Beckett: The Comic Gamut, New Brunswick (N.J.), Rutdgers, 1962 , p. 261 .

13. All French quotations are from the original En attendant Godot, Paris, Editions de Minuit, 1952, while the English translation is that of New York, Grove Press, 1954 edition. 
supportent pas) and finally from p. 152 (VLADIMIR : Un instant) to p. 153 (Lucky dépose les bagages... reprend les bagages). All that can be said of these cuts from our type of approach is that they are not justified. But while the reasons why the translator has left out such passages are not very pertinent here, they help to underline some of the differences between an ordinary translator (who translates other people's texts) and the self-translator (who translates what he himself has written). For the writer-self-translator, the act of translation is also an occasion for creativity.

Beckett's major fault (perhaps his only fault) as a translator is that his English translations never quite attain the deliberate colloquial style of his original works in French, his language of predilection and that in which he has written most of his works. Many examples in Waiting for Godot confirm this view :

Pour moi il est en train de crever :

Looks at his last gasp to me.

Ah non, là tu te goures :

Ah no, there you're mistaken.

It is quite obvious that crever and gourer are not words of neutral tonality like the expressions Beckett has matched with them. And in the following example, it is not so much the words as their arrangement which make for a discrepancy in tonality. Here the level of language is close to that of poetry, but only in English :

L'appel que nous venons d'entendre, c'est

plutôt à l'humanité qu'elle s'adresse :

To all mankind they were addressed, those cries for help still ringing in our ears ${ }^{14}$.

But in spite of these discrepancies - non-translation or difference in tonality - Beckett's translations are the best possible for most of his works. Cases where the author-translator correctly and completely renders the message of his original into the other language far outweigh those showing a contrary intention or lack of the ability to do so. In view of the amount of translation done, the surprising thing in fact is that there is so little to condemn. We never come acros cases of mistakes due to faux amis, for instance. Nor can Beckett be justly accused of bad translation as a result of not taking into account the different cultural heritages of both English and French.

However, perhaps because of the necessarily colloquial level of speech of his two main characters, the tramps Vladimir and Estragon, En attendant Godot poses less problems for the translator and consequently contains less that would call for the sort of ingenious translation Beckett is capable of. We find in this translation nothing comparable to the paranomasial tour de force with which was rendered into English Nagg's story in Fin de partie about the Englishman and his tailor, nor

14. It is because of this type of difference in level of speech that Ruby Cohn noted in her book, op. cit., p. 268 : "Despite all his willingness to translate three - and five letter French obscenities into a four-letter English norm, the French remains the more authentically colloquial of the two versions, and therefore the more comic. " 
is there that coitte and coite type of word-play which we have already cited in an earlier work on Beckett's bilingual dexterity ${ }^{15}$. All the same, a few translations clearly show the author's skill as a translator :

Qu'il lui fallait réfléchir... à tête reposée :

That he'd think it over... in the quiet of his home.

ESTRAGON : Quel est notre rôle là-dedans?

VLADIMIR : Notre rôle ? Celui du suppliant :

ESTRAGON : Where do we come in?

VLADIMIR : Come in? On our hands and knees.

In the second example above, Beckett shows that the translator really has to leave the words behind at one point and concentrate on the idea to be translated, if his translation must sound natural : the use of «come in $»$ to render rôle is a good example of the use of different thought-patterns in rendering the same idea i.e. «modulation». Elsewhere, Beckett translates the description of Pozzo's watch as follows :

une véritable savonnette... à secondes trotteuses :

a genuine half-hunter... with deadbeat escapement.

A savonnette is normally a « hunter » watch. But what makes it « half »? This is a personal solution of Beckett's, more so since he translates à secondes trotteuses as "with deadbeat escapement », a description which emphasises the quality of the watch.

If we now direct our attention to Beckett's techniques in rendering the message of SL, what stands out most clearly is that he does not in the least attempt to stick slavishly to the word to be translated. Nor does he practise the so-called free translation. What one notices is the skill in deciding when to use the literal method and when to resort to the «oblique » or indirect method, where literal translation is not adequate. The result is consistently good translation in which most of Vinay and Darbelnet's seven processes of translation are discernible :

\section{Literal/direct}

Un jour nous mourrons, le même jour, le même instant.

One day, we shall die, the same day, the same second.

Oblique/transposition : change in parts of speech

ayant longuement réfléchi.

after prolonged reflection.

je ne compte plus que sur toi. you're my only hope.

15. See chapter $\mathrm{v}$ of G. Ekundayo Simpson, le Bilinguisme de Samuel Beckett d'après ses traductions du français à l'anglais et vice versa, unpublished doctorate thesis, Université Laval, Québec, 1972. See also Blake T. Hanna, "Samuel Beckett : traducteur de luimême », in Meta 17, $\mathrm{n}^{\circ} 4$ (1972), p. 221-224. 
On ne commande pas à son humeur.

One is not master of one's moods.

Oblique/modulation : change in point of view

Lumière aveuglante. blazing light (cause/effect)

Il ne vaut plus rien ce fouet.

Worn out, this whip. (effect/cause)

Oblique/equivalence : in situation, proverbs, set phrases, etc :

C'est simple comme bonjour.

As simple as ABC.

Fous le camp. Go to hell.

Oblique/adaptation : cultural shifts

Normandie. Connemara.

Vaucluse. Macon country.

All that above techniques are used by Beckett, but the fact that modulation occurs more often than any of the other techniques emphasises the importance of this technique in translation.

On the other hand, Beckett's translation of En attendant Godot confirms certain facts about both languages to which comparative linguists have often called attention. One of these is the fact that while English words, especially the verbs, often conjure up in the mind a concrete image by their very nature, French words are often less concerned with concrete images. This can also be related to the higher level of abstraction on which the French language operates, compared with English. Hence the same verb tirer is equivalent to such image-evoking words as « puff », « drag » and « jerk » in the following translation of Beckett :

(II) tire sur sa pipe. (he)puffs at his pipe

(II) tire Estragon vers la coulisse.

(He) drags Estragon towards the wings.

(II) tire sur la corde. he jerks the rope.

The same phenomenon is illustrated in the following two examples :

Estragon court se mettre derrière l'arbre.

Estragon goes and crouches behind the tree.

Et ses yeux (...), Ils sortent.

And his eyes (...). Goggling out of his head.

To conclude this brief study of Samuel Beckett's translation of his own En attendant Godot, we shall once more recall the fact that his is the case of the translator who is also the creator of the original work. He therefore has access to that zone of creation which often remains inaccessible to the ordinary translator. 
What we gain by this coincidence is however, lost by the fact that this type of translator may in fact decide to cut off whole pages in translation and add other ideas, as Beckett has done precisely in his Waiting for Godot. But the bulk of it is good translation.

Finally, one may ask how the pendulum of translation criticism may be made to swing back in favour of linguistically oriented studies. Ideally, those who at present undertake different types of linguistic studies on questions which relate directly or indirectly to translation should be asked to take more interest in extensive translation criticsm. But since in practical terms it is not possible for many of such people to have the time, or the patience, for such work, the most reasonable thing would be to urge that they endeavour to supervise the work of more and more research students who will undertake comparative stylistic studies based on translation, or the study of translations starting from certain stylistic notions. Of course the corollary of this is to follow up Blake T. Hanna's call for the establishment of more undergraduate as well as graduate programmes in the discipline of translation.

EKUNDAYO SIMPSON 